\title{
DOE/NV/11417-- 6
}

\author{
GREAT BASIN PALEOENVIRONMENTAL STUDIES PROJECT \\ TECHNICAL PROGRESS REPORT \\ SECOND QUARTER (Year 2) \\ September - November, 1994 \\ Cooperative Agreement No. DE-FC08-93-NV11417
}

\author{
DESERT RESEARCH INSTITUTE \\ Quaternary Sciences Center \\ P.O. Box 60220 \\ Reno, Nevada
}

DISCLAIMER

This report was prepared as an account of work sponsored by an agency of the United States Government. Neither the United States Government nor any agency thereof, nor any of their employees, makes any warranty, express or implied, or assumes any legal liability or responsibility for the accuracy, completeness, or usefulness of any information, apparatus, product, or process disclosed, or represents that its use would not infringe privately owned rights. Reference herein to any specific commercial product, process, or service by trade name, trademark, manufacturer, or otherwise does not necessarily constitute or imply its endorsement, recommendation, or favoring by the United States Government or any agency thereof. The views and opinions of authors expressed herein do not necessarily state or reflect those of the United States Government or any agency thereof.

Submitted to:

U.S. Department of Energy

Yucca Mountain Site Characterization

Project Office

Las Vegas, Nevada 


\section{DISCLAIMER}

Portions of this document may be illegible in electronic image products. Images are produced from the best available original document. 


\section{Project Aim}

The paleobiotic and geomorphic records are being examined for the local and regional impact of past climates to assess Yucca Mountain's suitability as a high-level nuclear waste repository. In particular these data are being used to provide estimates of the timing, duration and extremes of past periods of moister climate for use in hydrological models of local and regional recharge that are being formulated by USGS and other hydrologists for the Yucca Mountain area. The project includes botanical, faunal, and geomorphic components that will be integrated to accomplish this goal.

\section{Project Goals:}

\section{Paleobotanical Studies In The Great Basin}

Dr. Peter E. Wigand, Principal Investigator

Paleobotanical studies are being used to reconstruct the community and organismal level responses of vegetation to past climate. Periods of moister climate during the last 20,000 to 50,000 years in the Yucca Mountain region have been identified during the last year and are being examined to generate estimates of their magnitudes, duration and environmental impacts. These studies are being scaled through comparisons with areas in the northern Great Basin that have been identified as potential modern analogue localities. These studies include an assessment not only of the modern and late Holocene (last 4,000 years) response of vegetation to changing climate, but also an analysis of the faunal and geomorphic impacts of these changes. These studies will provide an additional refinement of our understandings of the impacts of climate change so that our estimates of past effective precipitation changes can be distilled. These goals are being achieved in the paleobotanical section of these studies by:

1) extracting the high resolution climate signal in past rapid changes in vegetation community composition and productivity reconstructed from nearly continuous records of pollen in lacustrine sediments from southern Nevada and in modern and late Holocene analogue areas of northern Nevada and southern Oregon.

2) extracting the longer term effects of climate change in lagged changes in vegetation. community composition reflected in changes in the kinds plant species that appear through time in ancient woodrat middens at specific localities.

3) refining estimates of the duration and extremes of past moist events through analysis of the water stress-related carbon 13 content of index plant species recovered from ancient woodrat middens.

These data are being used to identify periods of much more mesic climate, and to provide information that can be used to estimate the magnitudes and durations of rainfall shifts by reference to modern distribution, characteristics and ecophysiological response of analogous plant communities and/or indicator species. Our determinations of the amounts and actual duration of the availability of excess water during these periods, in combination with those derived from the geomorphological studies being conducted by DRI, will be linked with the paleozoological indications of past climate to refine estimates of the duration and magnitudes of such excess water availability. Finally, ostracode and diatom analyses conducted by the USGS as part of the Lacustrine Studies of the Paleoclimate Phase of the Climate Program will provide reasonable indications of variations in climate that can be used to reconstruct past extremes in available precipitation that will serve as the best estimates of conditions that may be expected during the next 10,000 years at Yucca Mountain. Linked in this way, estimates of climate derived from the terrestrial environment can be compared with those derived from lacustrine environments to arrive at secure inputs for hydrological models of recharge. 
Project Tasks:

Palynological:

Task 1. Extend the present 2,000 year long vegetation history record from Lower Pahranagat Lake, southern Nevada for the purpose of providing baseline data for the generation of transfer functions for interpretation of less complete Pleistocene paleoclimatic proxy records. Lower Pahranagat Lake also provides the eastern terminus of a network of sites that straddle the Nevada Test Site and Yucca Mountain. As such, it will establish the regionality of any climate patterns that are revealed.

Progress: During the last quarter, we have completed magnetic susceptibility studies of the cores recovered during the summer from Lower Pahranagat Lake. We have begun core description and initiated sampling of the cores for pollen, ostracodes, diatoms and snails. We now have two sets of over-lapping cores comprised of a five-meter set covering the last 2,000 years and a second fifteen-meter set with a basal date of 5,500 b.p. Presently 128 samples are counted with a resolution of approximately a sample every 13 to 14 years. Preliminary results from ostracode samples from the first set of cores from Lower Pahranagat Lake submitted to Dr. R. Forester of the USGS and preliminary reported in the USGS milestones for August 1994 confirm some of the conclusions derived from the terrestrial pollen record with regards to the timing and magnitude of paleoclimatic changes. These data provide the high resolution well documented paleoclimatic data that will provide part of the analogue data for interpreting the less robust Pleistocene record of paleoclimate from southern Nevada. In addition, these data provide understandings regarding the nature of current variations in climate that might be expected in the near future.

Task 2. Assembly of a modern plant community pollen data base.

Progress: Assembly of modern plant community pollen data base is an on going effort being conducted at this time. Setting out passive pollen traps along elevational transects and near established weather stations so that modern weather data can be tied directly to the pollen record is ongoing. Samplers set out last winter will soon be collected for processing and analysis of the pollen.

Task 3. Assembly of available palynological data from the Intermountain West into a data base, including the augmentation of the data from some of the localities previously examined by us in order to accomplish the goals of the project. This includes the submission of radiocarbon dates and tephra analyses for the resolution of chronologies, and analyses of pollen samples taken at closer intervals to resolve the rates of climate change, their magnitude and the response of the vegetation community.

Progress: Assembly of available palynological data from the Intermountain West into a data base is ongoing.

Task 4. Coring of selected southern Nevada localities for paleoenvironmental records.

Progress: The requisite state-wide and local permits have been obtained from the BLM and Fish and Wildlife Service have been obtained for the coring of selected southern Nevada localities for paleoenvironmental records. However, we have received provisional permission to core 
Indian Springs Playa and Three Lakes Playa, we are still awaiting security clearance from the Air Force to conduct our research on Nellis AFB. We hope to be coring the area between Lower and Upper Pahranagat lakes in winter of 1994/95. This will of course be constrained by how wet the playas are at the time that we receive permission.

\section{Paleonidological:}

Task 5. Assembly of available woodrat midden data from the Intermountain West into a data base.

Progress: Assembly of available woodrat midden data from the Intermountain West into a data base has been one of the major focuses of this quarter's activities. This has included proofing of the data base, and adding the results of other analyses that we are conducting as they are completed. In addition, we have contacted previous investigators from the Great Basin and have received their co-operation in direct dating and stable isotope analysis of index plant species materials that were previously collected by them but never directly dated. This will greatly improve the robustness of the current data base. In addition, we are conducting preliminary analyses of vegetation data in this data to determine the protocols that we will use in its analysis.

Task 6. $\quad$ Process samples already collected that are pertinent to the goals of the project.

Progress: Samples previously collected from the Pahranagat Range of southern Nevada are continually being processed. Plant macrofossil materials from additional midden strata for radiocarbon dating to confirm the age and association of indicator species are being gathered to be ready to submit whenever the USGS subcontract with Beta Analytic is in place. Carbon-13 isotopic analyses on the cellulose of indicator species will be run on materials from these midden strata as they are dated. Insect remains from these woodrat midden samples continue to be analyzed by Dr. S. Elias, a subcontractee.

Task 7. Collection of modern vegetation and climate data pertinent to interpretation of woodrat midden data in an analogue/nonanalogue manner.

Progress: Collection of modern vegetation and climate data pertinent to interpretation of woodrat midden data for use in analogue/nonanalogue comparisons is on going. These localities correspond, in as much as is possible, with the pollen collection localities mentioned above. As these activities are linked to the QA portion of the project, they are being funded through our contract with the USGS.

Task 8. Select, collect and process new midden localities that are pertinent to the goals of the project.

Progress: Due to monetary and current project deadline constraints, no new collection or recollection of old localities in southern or central Nevada was conducted during this period. Nor do we anticipate such collection. 


\title{
Problems Encountered:
}

Still waiting on the Air Force security clearance for Nellis AFB work. Sufficient funding is not available to meet the objectives for this project.

\author{
Paleofauna Studies in the Great Basin \\ Dr. Stephanie Livingston, Principal Investigator
}

\section{Project Goals}

The goal of this study is construct a history of Great Basin vertebrates, particularly mammals, that which will provide empirical evidence of past environmental and climatic conditions within the Great Basin as it is recorded by the animals. Taxonomic composition of archaeological and paleontological faunas from various areas within the Great Basin and morphological change within individual mammalian taxa at specific localities are being investigated to monitor faunal response to changing environmental conditions. Data are being obtained from published records, modern museum specimens, and raptor pellets to provide a modern control to which the paleofaunal data can be compared. This study will provide an independent set of surrogate data for use in building a model of past conditions and assessing the effects of past climate change on various aspects of the environment.

\section{Progress on Tasks:}

Task 1. Data collection from existing paleontological and archaeological vertebrate collections.

Progress: Analysis of the birds from the four lower levels representing the late Pleistocene/early Holocene at Homestead Cave has been summarized in a brief report, and analysis of the smaller screen sample is continuing. Sorting and analysis of the levels thought to represent the middle Holocene has begun. Radiocarbon age control for this site is expected in December. The Floating Island avifaunal analysis is nearing completion.

Task 2. Field work conducted from which collections for analysis will be obtained.

Progress: We have started the permitting process to obtain permission to test a site in the Silver Peak Range near Fish Lake Valley.

Task 3. Data collection from existing museum collections for modern standards.

Progress: No progress was made on this task during this quarter.

Task 4. Integrative analysis.

Progress: Progress in continuing in construction of the GIS model.

Problems Encountered:

None to report at this time. 


\section{Geomorphology Studies in the Great Basin \\ Dr. Nicholas Lancaster, Principal Investigator \\ Dr. Jerry Miller, Co-Principal Investigator \\ Mr. Fred Nials, Co-Principal Investigator}

\section{Project Goals:}

The objective of the geomorphology component of the paleoenvironmental program is to document the responses of surficial processes and landforms to the climatic changes documented by studies of packrat middens, pollen, and faunal distributions. This major objective will be achieved by a variety of projects designed to reveal the linkage between climate change and physical response. The project will focus on: 1) stratigraphic relationships between lake deposits and aeolian or fluvial sediments and land forms; 2) cut and fill sequences in floodplain and river-channel deposits; 3) identification of periods of dune mobility and stability; 4) documentation of episodes of alluvial fan and terrace development and erosion; and 5) correlation of number 3 and 4 to climatically driven lake-level fluctuation as revealed by shoreline features such as strandlines and beach ridges. Numerical and relative dating of geomorphic events will be accomplished by a range of techniques including $\mathrm{C}^{14}$, tephrochronology, dendrochronology, luminescence, and soil chronology.

\section{Progress on Tasks:}

\section{Task 1: $\quad$ Lacustrine Stratigraphy and Chronology}

Progress: Investigations in the past 3 months have focused on refining the sequence and correlating shoreline elevations in different parts of the Fernley Basin. On the basis of this work, we have sampled localities for shells for AMS 14C dating. We have continued sediment analyses of sampled collected last summer. The planned sediment cores mentioned in the last report have not been taken due to the early onset of winter this year. We hope to do this in the early summer.

\section{Task 2. Alluvial fan response to climatic change}

Progress: Within the past three months, ten C-14, AMS dates have been obtained on mollusks shells extracted form lacustrine deposits within Buena Vista Valley, central Nevada. These dates have been used to constrain the age of several shoreline features (including the highest) and develop a crude lake level curve for the late Pleistocene. Assuming the dates are valid, the high-stand within this subbasin of Pluvial Lake Lahontan occurred between 12,500 and 13,100 (note dates on shells are typically young). These ages for the high-stand roughly match those provided by L. Benson from the USGS and his colleagues for the Pyramid Lake subbasin, but are in conflict with other data currently being extracted form the Black Rock Desert area. We are now in the process of assessing the validity of our shell dates.

In addition, a preliminary geomorphic model of alluvial fan development has been developed in consultation with the project PI's for the Klondike Canyon Fan by Jennifer Husek, a graduate assistant conducting a M.S. thesis on the subject (and working on this project). This model will be finalized in the coming three months and presented as a completed M.S. thesis. 
Progress: We are continuing to assemble data from the various areas. Stratigraphic and geomorphic studies, together with luminescence dating have established that five main periods of enhanced eolian activity have occurred in the Afton Canyon to Kelso dunes eolian sediment transport system in the past $25 \mathrm{ka}$. The extent and character of these periods varies through time. Phase I ( 25 to $16.8 \mathrm{ka}$ ) was characterized by the formation of now relict sand ramps at several localities, and eolian deposition as much as $5 \mathrm{~km}$ east of Kelso Dunes. Interestingly, this phase of eolian activity occurred coeval with lake highstands (Lake Mojave I: 20.9 to $16.9 \mathrm{ka}$; Lake Mannix 23.5 to $20.8,17.6$ to $16.5 \mathrm{ka}$, calibrated ${ }^{14} \mathrm{C}$ ages). A period of much more mesic climate and high lake levels and river discharge (Lake Mojave II, 16.5 to 13.4 ka) was associated with eolian stability and soil formation on sand ramps. Phase II (12.5 to $3.5 \mathrm{ka}$ ) involved renewed sand ramp accumulation in some localities and formation of dunes and sand sheets on the east margin of Kelso dunes. The first part of this phase was associated with desiccation of Lake Mojave II after $13.4 \mathrm{ka}$ with final desiccation at $9.7 \mathrm{ka}$. The later part reflects mid Holocene aridity in the region Spaulding, 1991 \#1677. There was a major period of dune stabilization at Kelso 3.5 to $4 \mathrm{ka}$ in conditions of increased regional rainfall. Phases III ( 2.0 to $1.5 \mathrm{ka})$, IV ( 0.8 to $0.4 \mathrm{ka})$, and V (0.25 to $0.15 \mathrm{ka})$ were associated with dune reactivation at Kelso and small-scale accumulation of dunes in the Cronese basin. They are probably associated with periods of regional drought, as well as enhanced sediment supply from periods of increased discharge in the Mojave River system at around $0.39 \mathrm{ka}$

\section{Publication:}

Response of eolian geomorphic systems to Late Pleistocene and Holocene climatic change in the Mojave Desert, N. Lancaster, and A.G. Wintle, M.L. Clarke, H.Rendell, V.P. Tchakerian, Geological Society of America, Abstracts with Programs, 26, 1994 Annual Meeting, A-89.

Task 4. The geologic record in northern Nevada: Applications to archaeological investigations.

Progress: Field activities were concentrated on two areas of investigation. Additional sediment cores were collected from the Black Rock Desert area (Lake Lahontan) for additional calibration of the paleomagnetic record in lacustrine sediments. A previously undescribed "spike" that should be useful for sediment correlation has been analyzed by Inga Ewing, a graduate student at CSU-Bakersfield. A description of the paleomagnetic properties of the Black Rock sediment cores is the subject of her thesis.

A second focus of activities during the quarter was additional field evaluation of Holocene alluvial sequences in northern and central Nevada. The purpose of the examination is to further refine the timing of significant erosional/depositional events, and to assess the role of climate in initiating such events. Four new locations were located that contain radiocarbon and/or archaeological materials suitable for dating. These locations appear to confirm the presence of a consistent climate-related sequence of alluvial events throughout northern and central Nevada. This sequence has now been tested widely as a means of predicting the locations and timing of archaeological manifestations, with consistent affirmative results. 
Two papers were presented at the Great Basin Archaeological Conference, Elko, Nevada, describing the alluvial sequence and the archaeological and paleoenvironmental significance. Titles and abstracts are enclosed.

Geologic investigations at several locations in northern Nevada show repeated cycles of arroyo-cutting and alluviation. These cycles appear to be directly related to changes in type, intensity, and focus of geomorphic processes induced by climate fluctuations, and documented by dendrochronologic records. Because valley-bottom processes typically are related to processes in non-alluvial environments, the chronology of alluvial events provides a context for evaluation of human/land interactions. Within limits, land-surface processes associated with climate variation are predictable, allowing for the development of locationspecific geomorphic models of past human activities. Such models, coupled with alluvial and dendroclimatic records, expedite the search for buried sites and interpretation of distribution of archaeological materials in some depositional environments of the northern Great Basin.

Task 5. Holocene climate variations: Potential effects on archaeological evidence.

Progress: Geomorphic processes often play a major role in the distribution of archaeological sites and integrity of site contents. In the Great Basin, these processes are controlled by a complex interaction of tectonic activity, topographic position, vegetation, fluctuating lake levels, and climate. Sufficient paleoenvironmental data has been collected from the Great Basin in recent years to begin the evaluation of climate/geomorphic process factors of site location and transformation processes. This study has been enhanced by the recent completion and reanalysis of two unusually long dendrochronological records. These chronologies, from the White Mountains of California (8,600 years) and the White Pine Range of central Nevada (5,200 years), provide accurate records of precipitation variation in a temporally precise context. The records also reveal or confirm the existence of several major drought episodes and periods of higher precipitation. Major climate shifts are shown to occur very rapidly, literally within the span of decades or less. The precision of the chronologies allows more informed evaluation of dominant geomorphic processes through time and their impact on archaeologic sites.

Problems Encountered:

Sufficient funding is currently not available to meet the objectives of this project. 


\section{Transportation}

Dr. Richard French, Principal Investigator

\section{Project Goal:}

The focus of this project during this quarter has been the completion of the analyses using the FLO-2D and DAMBRK computer programs. A sensitivity analysis of FLO-2D regarding multiple channel zones versus single channel zones was performed on the model of the largest alluvial fan to determine any significant impact of results. The change in results was negligible when considered relative to the level of effort required to make these adjustments. Detailed analyses of aerial photos, topographic maps, and AutoCAD-generated grid systems, along with field verifications were necessary to make an accurate assessment of multiple- versus single-channel areas of the fan surface. This same analysis was performed on a smaller fan. It was again found that an extensive level of effort was required to make an accurate assessment of channel types on even a small fan with negligible impact on result.

All alluvial fans included in this study have been analyzed using the DAMBRK computer program. Results of these analyses suggest that fans with lower slopes are more difficult to model than those with steeper slopes. This finding is consistent with results from previous alluvial fan applications of this model.

Difficulties with the FESWMS-2DH computer program are assumed to be related to slope. FESWMS$2 \mathrm{DH}$ was developed to model flow through natural river systems where typical slope values are less than $0.0001 \mathrm{ft} / \mathrm{ft}$. Slopes of the alluvial fans included in this study are at least two orders of magnitude greater than those of natural river systems. Jim O'Brien, FLO Engineering, has suggested that the slopes associated with these alluvial fans may cause FESWMS-2DH to use a dynamic wave instead of a kinematic wave routing method. Thus, this approach may be inappropriate for use in modeling alluvial fans. The USGS has stated that FESWMS-2DH was not intended to model alluvial fans and has also suggested that the difficulties encounter with use of this model are probably due to the fan slopes being greater than those of natural river systems. The USGS has been requested to concur in writing with this determination.

Problems Encountered:

Sufficient funding is currently not available to meet the objectives of this project. 